doi: https://doi.org/10.15407/dopovidi2018.12.093

UDC 615.(212/213)-577.35/57.053

\author{
N.Ya. Golovenko ${ }^{1}$, S.A. Andronati ${ }^{1}$, \\ V.B. Larionov ${ }^{1}$, A.S. Reder ${ }^{2}$ \\ ${ }^{1}$ A.V. Bogatsky Physico-Chemical Institute of the NAS of Ukraine, Odessa \\ ${ }^{2}$ SLC "InterChem", Odessa \\ E-mail: n.golovenko@gmail.com,office.physchem@nas.gov.ua, \\ vitaliy.larionov@gmail.com, reder@interchem.com.ua
}

\title{
A pharmacological profile of propoxazepam - a new antiepileptic substance
}

Presented by Academician of the NAS of Ukraine S.A. Andronati

The analysis of the dose-effect pharmacological action for propoxazepam on the models of chemically and electrically induced seizures is carried out. The peculiarities of the compound influence on the different genesis seizures manifestations and their redistribution are determined. Pharmacological indices (therapeutic index, wideness, interval, and safety factor) have been calculated, which characterize the efficacy and safety of propoxazepam. The data presented suggest that the future use of propoxazepam as an antiepileptic agent is more secure in those pathologies that are more relevant to the GABA- and glycine-ergic mechanisms.

Keywords: propoxazepam, chemical and electrical convulsants, therapeutic index, therapeutic wideness, therapeutic interval, safety factor.

Epilepsy refers to chronic polyethyologic diseases of the brain characterized by recurrent seizures that occur as a result of excessive neuronal discharges and are accompanied by various clinical and paraclinical symptoms. Anticonvulsant therapy remains the basis for treating patients with epilepsy, which involves the inhibition or a significant reduction in the number of attacks. Currently, the term "antiepileptic" is synonymous with anticonvulsant agents, as they all selectively suppress seizure, and their use is determined predominantly by the nature of paroxysmal manifestations or their equivalents. Depending on the clinical manifestations of epilepsy, different anticonvulsants can be prescribed. Often, for the treatment of epilepsy, the combined use of several medicines is rational (simultaneously or sequentially). Therefore, the success of a treatment of epilepsy is on the way to finding new anticonvulsants, which would have had an effect on different pathogenetic links in the formation of all variabilities of seizure states [1].

Antiepileptic drugs act on different molecular targets, selectively changing the excitability of neurons in such a way that the neuronal activity, associated with attacks, is blocked without disturbing the normal activity required to transmit signals between neurons. Various mecha- 
nisms can lead to reducing the excitability of the neurons of the epileptogenic focus. Basically, they consist either in inhibiting activating neurons, or in activating inhibitory nerve cells, i. e, they are reduced to three major pharmaco-neurophysiological effects: relief of GABA or glycine-dependent transmission, reduction of excitatory (glutamate or aspartate) transmission and nonspecific modification of ion currents (sodium, calcium, and potassium channels). At the same time, it is believed that the most effective control of seizure readiness is realized precisely because of GABA-ergic mechanisms [2,3].

Despite the fact that these medicines take maximum account of the mechanisms of epileptogenesis, the issue of improving their effectiveness is still relevant.

A number of novel 3-substituted 1,4-benzodiazepines have been synthesized at the PhysicoChemical Institute of the National Academy of Sciences of Ukraine, and their structure-activity relationships were studied [4]. Their pharmacological effect was unusual, as, unlike most drugs in this class, in the models of nociceptive and neuropathic pain, these substances showed a significant analgesic activity; one of them, propoxazepam, 7-bromo-5-(o-chlorophenyl)-3propoxy-1,2-dihydro- $3 \mathrm{H}$-1,4-benzodiazepin-2-one, is considered as a promising drug and is undergoing preclinical trials.

Similar to gabapentin and pregabalin, which are well-known drugs used in general medical practice in the treatment of neuropathic pain [5], propoxazepam also has an anticonvulsant effect, which explains the analgesic component of the pharmacological spectrum [6-8].

The aim of this work is the propoxazepam pharmaological profile analysis on the models of different seizures (chemically and electrically induced) and the determination of the propoxazepam influence on manifestations and redistribution on different seizures for pharmacological indices (therapeutic index, therapeutic wideness, therapeutic interval and safety factor) calculation.

Materials and methods. Experiments were performed on outbred white mice of both sexes weighing 20-22 g. All experimental procedures were conducted in accordance with the rules of the "European Convention for the Protection of Vertebrate Animals, Used for Experimental and Other Scientific Purposes" in accordance with the Directive of the Council of the European Union 86/609 of the EU of November 24 1986. During experiments the animals were kept under standard conditions (12-h light-shade mode and with access to water and food ad libitum).

The use of different seizures inducers (picrotoxin (PCT), penthylenetetrazole (PTZ), strychnine (STR), thiosemicarbazide (TSC), bemegride (BMG), 4-aminopyridine (4-AP), and maximal electroshock (MES) allowed us to model different paroxyzmal manifestations and to suggest the propoxazepam mechanisms of antiseizure action.

The test compound was administered intraperitoneally (in a tween emulsion) at doses, whose choice of boundaries was based on previous pilot studies and the requirements of statistical and calculation methods. Solutions of chemoconvulsants (at doses causing the lethal effect in $95 \%$ of animals) were administered subcutaneously to animals (6-8 mice in each experimental group) 30 min after propoxazepam administration. The counting time of the experiment started from the moment of seizure agent administration. During the observation period, the number of myoclonic tremors and generalized attacks in the form of tonic extensia, as well as the time before the onset of the lethal effect, were recorded. To characterize the representativeness of each seizure types, the experimental data are presented in the relative form $(M \pm m)$ of the total number of recorded seizure episodes. 
Since the mechanism of convulsions development under the action of thiosemicarbazide involves a long exhaustion of endogenous GABA, the observation of animals was carried out within $3 \mathrm{~h}$, indicating the number of individual components of convulsive attack (myoclonic tremor, generalized attacks in the form of tonic extension, the total number of cases of these types, and the time of their manifestation ) and total time to the lethal effect, marking the time periods since the chemoconvulsant administration. During the next $24 \mathrm{~h}$, the end-lethal effect was recorded in each group of animals, which gave an opportunity to evaluate the possible time-dependent effects of propoxazepam and the general characteristic of its protective effect. The analysis of the lethal effect was carried out in an alternative form, by the number of animals that survived in experimental groups

Evaluation of the lethal effect was carried out in an alternative form (presence or absence of effect). The protective effect of the substance (the value of $\mathrm{ED}_{50}$ ) was estimated by the number of animals (frequency of effect) that survived in each individual group. The calculation of $\mathrm{ED}_{50}$ values was carried out using the probability of developing the effect by the Kerber method (corrected by the Barren method) and probit analysis [9]. The reliability of the differences between the control and experimental groups for the individual parameters of convulsive activity (after the previous analysis for compliance with the normal distribution law), as well as the final experimental data, were assessed on the basis of the Student's criteria or non-parametric statistics methods (Wilcoxon-Mann-Whitney Criteria) [10].

Results and their discussion. The results presented in table 1 indicate a high protective activity of propoxazepam based on the data of the dose-effect curves: PCT $1.67 \pm 0.09$, PTZ $0.9 \pm 0.04$, STR $14.24 \pm 0.47$, MES $0.57 \pm 0.23$, TSC $0.18 \pm 0.09$, 4-AP $37.3 \pm 7.9 \mathrm{mg} / \mathrm{kg}$. Changing the time of onset seizures and their redistribution in the course of an epileptic syndrome makes the compound promising in the epilepsy treating.

The specific feature of the used convulsive agents is the different structure of different seizures representation. For nearly all the chemical convulsants used (except 4-AP), typically the tonical component is represented as major (more than $70 \%$ ). It is possible that such ratio is determined by the peculiarities in their action mechanisms and the rate of primary focal epilepsy center transformation to the dominant one with paroxysmal activity. For example, the most myoclonic component representation is noted for PCT, whose action mechanism is chloride ions current through the ionophore channel of $\mathrm{GABA}_{\mathrm{A}}$-receptor with the simultaneous decrease of its average open-state time. PTZ is the most similar to PCT by its action mechanism, being the nondirect concurrent $\mathrm{GABA}_{\mathrm{A}}$-receptor antagonist, having the binding sites in the cavity of the ionophore channel. Thus, for receptor channel blocking by PTZ, the primary activation of a receptor is necessary, which explains the nearly absence of the clonic component in a PTZ-induced structure of seizures. For TSC, which blocks the GABA reserve restoring, the fast generalization of excitation, leading to the development of tonic seizures (mostly $100 \%$ of seizures) is the main feature. Despite the BMG action also develops through the GABA-ergic system (barbiturate-binding site blocker), there is also a little manifestation of the myoclonic component ( $2 \%)$. The higher part of the myoclonic component (5.8 \%) is in STR-induced seizures (concurrent antagonist of glycine receptors, mainly concentrated in the spinal cord and controlling peripheral signals transmission).

Convulsive action of MES develops through the total depolarization of brain neurons, caused by electric discharge, which generates the tonical component of seizures. Among the 
described convulsants, the myoclonic component is mostly represented $(67 \%)$ in the 4-AP-induced seizures, whose action mechanism is in the potassium channels blocking and repolarization inhibition.

The results obtained provide the possibility to determine the proxazepam antiseizure profile in various models of epileptic seizure, taking into account that the development of tonic seizures is associated with more severe and generalized CNS excitations, which is more difficult to block as compared to the formation of primary epileptopoietic focci (which are accompanied by myoclonic types of convulsions). The effect of propoxacepam on the structure of the epileptic attack was evaluated at the dose, which has the maximum protective effect, but does not block the development of separate types of seizures (see Table 1). Depending on the type of chemoconvulsant, the protective dose of propoxazepam is significantly different (from $0.32 \mathrm{mg} / \mathrm{kg}$ for TSC up to $80 \mathrm{mg} / \mathrm{kg}$ for 4-AP), indicating a different degree of interaction with biotargets. Obviously, propoxazepam is more effective on the GABA-ergic dysfunction models, what is proved by a rise of the myoclonic component representation in the seizures structrure with the simultaneous decrease of the tonic component. We have to mention that, on the BMG-induced seizures model, the relative quantity of the myoclonic component is only $32 \%$. This suggests the comparatively separate influence of benzdiazepine- and barbiturate-allosteric centers control.

MES-induced seizures blocking demands the strong and steady cells hyperpolarization. Thus, the propoxazepam efficiency in this model is not very high. Moreover, even the relatively high doses $(20 \mathrm{mg} / \mathrm{kg})$ don't suppress the tonic component (68 \%) possessing nevertheless, the protective action.

The attention is attracted by the fact that in the model of 4-AP-induced seizures, propoxazepam not only shares the negligible effect (94\% of protective action is reached at a dose of

Table 1. $\mathbf{L D}_{95}$ indices of different convulsion-inducing agents, propoxazepam $\mathbf{E D}_{50}$ and the relative representation of the clonic and tonic components in mice, as well as their change with the propoxazepam administration

\begin{tabular}{|c|c|c|c|c|c|c|c|}
\hline \multirow{5}{*}{ Seizures type } & РCT & PTZ & STR & TSC & BMG & 4-AP & MES \\
\hline & \multicolumn{7}{|c|}{$\mathrm{LD}_{95}(\mathrm{mg} / \mathrm{kg})$} \\
\hline & 6.5 & 120.0 & 2.0 & 20.0 & 56.0 & 10.3 & \\
\hline & \multicolumn{7}{|c|}{ Propoxazepam. $\mathrm{ED}_{50}(\mathrm{mg} / \mathrm{kg})$} \\
\hline & $1.67 \pm 0.09$ & $0.9 \pm 0.1$ & $14.2 \pm 0.5$ & $0.2 \pm 0.09$ & $0.39 \pm 0.1$ & $37.3 \pm 8$ & $0.57 \pm 0.3$ \\
\hline & \multicolumn{7}{|c|}{ The relative quantity of different seizures in the control group } \\
\hline $\begin{array}{l}\text { Myoclonic } \\
\text { Tonic }\end{array}$ & $\begin{array}{l}25 \\
75\end{array}$ & $\begin{array}{c}0 \\
100\end{array}$ & $\begin{array}{c}6 \\
94\end{array}$ & $\begin{array}{c}0 \\
100\end{array}$ & $\begin{array}{c}2 \\
98\end{array}$ & $\begin{array}{l}67 \\
33\end{array}$ & $\begin{array}{c}0 \\
100\end{array}$ \\
\hline & \multicolumn{7}{|c|}{ Propoxazepam dose (mg $/ \mathrm{kg})$ and maximal reached protective effect (\%) } \\
\hline Seizures type & $\begin{array}{c}8 \\
(100 \%) \\
\end{array}$ & $\begin{array}{c}3 \\
(100 \%) \\
\end{array}$ & $\begin{array}{c}32 \\
(80 \%) \\
\end{array}$ & $\begin{array}{c}0.32 \\
(100 \%) \\
\end{array}$ & $\begin{array}{c}0.8 \\
(100 \%)\end{array}$ & $\begin{array}{c}80 \\
(94 \%) \\
\end{array}$ & $\begin{array}{c}20 \\
(100 \%) \\
\end{array}$ \\
\hline $\begin{array}{l}\text { Myoclonic } \\
\text { Tonic }\end{array}$ & $\begin{array}{c}93 \\
7\end{array}$ & $\begin{array}{l}65 \\
35\end{array}$ & $\begin{array}{l}26 \\
74\end{array}$ & $\begin{array}{l}75 \\
25\end{array}$ & $\begin{array}{l}32 \\
68\end{array}$ & $\begin{array}{l}13 \\
87\end{array}$ & $\begin{array}{l}32 \\
68\end{array}$ \\
\hline
\end{tabular}


$80 \mathrm{mg} / \mathrm{kg}$ ), but also unusually redistributes the myoclonic and tonic components (reducing the firs and increasing the second component).

Such peculiarities in the anticonvulsant action can be explained from the position of potassium ion channels functioning, which are inhibited by 4-AP. It is known that their activation leads to the membrane repolarization after the action potential development (participation in the potential restoring). Thus, paying attention to such an "antiepileptic" effect, it is possible to suggest the division of propoxazepam and 4-AM actions - first one acts predominantly on postsynaptic $\mathrm{GABA}_{\mathrm{A}}$-receptors, causing the cell hyperpolarization, while the second interferes both pre- and postsynaptic potassium channels of the cell. Obviously, such an influence leads not only to the hyperpolarization efficiency reducing, but also increases the cell refractory period. Because of it, even the high doses of propoxazepam doesn't share the 100-\% efficiency in this model.

On the base of the obtained data, the main indices (therapeutic index, therapeutic wideness, and safety factor), which characterize the propoxazepam safety use, were calculated. Therapeutic index (TI) determines the interval between the equipotential doses (causing the equivalent effect in \%). Usually, it is determined as the ratio of mean effective doses of the lethal $\left(\mathrm{LD}_{50}\right)$ and therapeutic $\left(\mathrm{ED}_{50}\right)$ effects - the bigger this indicator, the more safe the medicine use.

Therapeutic wideness (or "therapeutic window", TW) is the dose diapason between the minimal therapeutic and minimal toxic ones. As the accuracy of the compound minimal toxic dose value depends on the quantity of subjects, its empirical values are changed to calculate the threshold effect $(1 \%), \mathrm{TW}=\left(\mathrm{TD}_{1}-\mathrm{ED}_{1}\right)$. This indicator characterizes the doses interval, which can be used without toxic effects appearing. It is a more reliable safety indicator, since it reflects the degree of side effects appearing on the dose-effect curve. As its dimension is dose-dependent, it is used together with the Therapeutic Interval (TInt) indicator, which represents the compound influence on organism (TInt $=\mathrm{ED}_{99}-\mathrm{ED}_{1}$ ). The higher this indicator, the higher the dose needed for the desired effect reaching. These intervals overlapping (TW TInt) testifies to the toxic effects appearing at doses, which cause no therapeutic effect at most of treated subjects.

Safety factor (SF) is the ratio of minimal toxic dose to maximal effective one $\left(\mathrm{SF}=\mathrm{TD}_{1} /\right.$ $\mathrm{ED}_{99}$ ) and reflects the possibility of degree, in which the therapeutic dose can be increased without the risk of intoxication. As well as the therapeutic index, SF is a dimensionless parameter and can be used for the comparative estimation of different compounds. Because, during the $\mathrm{LD}_{50}$ determination, the lethal effect hadn't been reached, the lower limit in the further calculations was assumed to be a $5000 \mathrm{mg} / \mathrm{kg}$ as that tested in the experiment. This value became the basis for the comparative characterization of the compound safety under the conditions of different genesis seizures. The given data (table 2, figure) prove that the highest propoxazepam safety is in the PTZ-induced epileptic syndrome (clonical, clonical-tonical and generalized seizures), because, for this model, the highest values of all the indicators are determined (see table 2) along with low TInt value, which suggests the quick effect increase with the raising dose. The high TI values for TSC and MES tests (see table 2) also demonstrate a high safety of the compound use at GABA-deficient

Table 2. Propoxazepam safety indices

\begin{tabular}{|l|c|c|c|c|}
\hline $\begin{array}{c}\text { Seizure } \\
\text { inducer } \\
\text { in test }\end{array}$ & TI & SF & TW & TInt \\
\hline PTZ & 5556 & 4379 & 5000 & 0.33 \\
PCT & 2994 & 2243 & 4999 & 0.75 \\
TSC & 27778 & 1908 & 5000 & 2.6 \\
MES & 10000 & 851.0 & 5000 & 5.7 \\
STR & 351 & 294.2 & 4988 & 3.8 \\
4-AP & 134 & 43.1 & 4988 & 93 \\
\hline
\end{tabular}




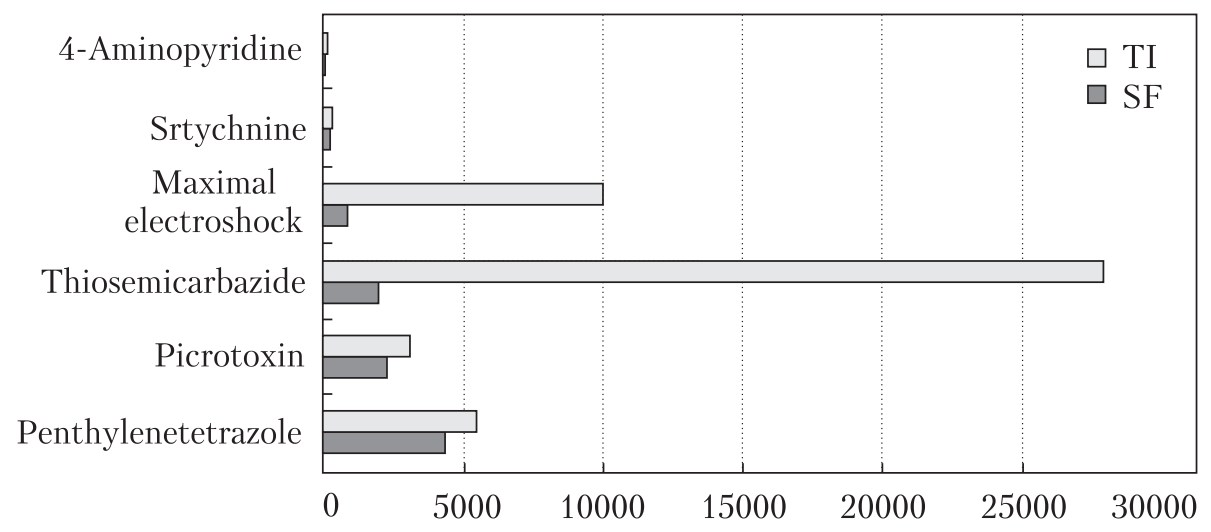

Comparative propoxazepam characterization on the base of TI (therapeutic index) and SF (safety factor) values

pathologies and primary-generalized seizures (status epilepticus), as well as partial paroxyzms in the MES model. But the TW factor is notably reduced (1908 and 851, respectively, see figure). Moreover, as compared to the PTZ-induced seizures test, this indicator shows no significant effect increase with dose raise. Both effective dose and TInt increase for propoxazepam suggest its little possibility to block STR- and 4-AP-induced paroxyzmal manifestations. Thus, the SF values proved that the propoxazepam use is more safe and efficient for the treatment of pathologies, which correspond to its mechanism of action.

Comparison of the spectrum of anticonvulsant action of propoxazepam with the majority of medicines used to suppress specific epileptic syndrome (table 3 ) showed its preference. Only valproate, as in propoxazepam, is characterized by the inhibition of all variabilities of convulsive states. According to the main hypothesis, valproate stimulates GABA-ergic mechanisms, by inhibiting the GABA-transferase enzyme, which leads to an increase in the content of GABA in the

Table 3. The effectiveness of antiepileptic medicines for different types of seizures

\begin{tabular}{|l|c|c|c|c|c|}
\hline \multirow{2}{*}{\multicolumn{1}{|c|}{ Medicines }} & \multicolumn{7}{|c|}{ Seizures type } \\
\cline { 2 - 6 } & Partial & Tonic-clonic & Absences & Myoclonic & Atonic-tonic \\
\hline Phenobarbital & + & + & + & 0 & $?$ \\
Phenytoin & + & + & - & - & 0 \\
Carbamazepine & + & + & + & + & 0 \\
Valproate & + & + & + & + & + \\
Tomiramat & + & + & $?$ & + & + \\
Gabapentin & + & + & - & - & 0 \\
Lamotrigine & + & + & + & + & + \\
Ethosuxumide & 0 & 0 & + & + & $?$ \\
Levetiracetam & + & + & + & + & + \\
Felbamate & + & + & + & + & $?$ \\
Vigabatrin & + & + & + & + & + \\
Propoxazepam & + & + & + & + & + \\
\hline
\end{tabular}

Note. "+" - effective; "? + "- maybe effective; "0" - ineffective; “-" - increased attacks; "?” - unknown 
central nervous system. Another mechanism for increasing the GABA-ergic activity is the direct influence of valproate on postsynaptic receptors (especially, GABA-RK), which simulates or enhances the effect of GABA. In addition, the drug has a direct effect on the potential-dependent sodium channels and can affect the activity of the membranes, changing the permeability for potassium ions [11].

At the same time, when comparing experimental data on the "gold standard" of screening drugs on models of seizures caused by PTZ and MES [12], it is noticeable that, according to the values of $\mathrm{ED}_{50}$, propoxazepam predominates valproate [propoxazepam $(0.92 \pm 0.38 / 0.57 \pm$ $\pm 0.23 \mathrm{mg} / \mathrm{kg})$, valproate $(271.7 / 148.6)]$.

Taking into account the fact that propoxazepam refers to derivatives of 1,4-benzodiazepine, it is necessary to compare the indicated parameters with the drugs of this group. So, diazepam has the following ratio of MES/PTZ tests in mice, $\mathrm{mg} / \mathrm{kg}$ (3.5/0.52); clonazepam (7.5/0.06); nitrazepam (4.5/0.27); phenobarbital (21.8/13.2). Some anticonvulsants (phenytoin, carbamazepine) do not affect seizures caused by penthylenetetrazole, but are active in relation to MES (9.5 and 8.8, respectively). With regard to the significant difference in the ratios of MES/PTZ ratios of related compounds (1,4-benzodiazepines) having similar mechanisms of action, their explanation may be data on the structure of GABA-RK for which the effect of PTZ is often characterized as "noncompetitive" in relation to anticonvulsants of 1,4-benzodiazepine [13]. Note that the part of GABA-RK is represented by a number of subtypes, among which $a 4 b 3 d, a 3 b g 2$, $a 3 b g 2, a 1 b g 2$ are responsible for the seizure effect of chemoconvulsants. Moreover, each benzodiazepine prefers a specific receptor subtype [14]. So, diazepam, clonazepam, and nitrazepam are high-affinity compounds of $a 2$ and $a 3$ receptors.

The results of the study prove the high safety of propoxazepam use for the treatment of GABA-associated pathologies and primary-generalized seizures (status epilepticus) in the tests of TSC- and MES-induced seizures, as well as MES-induced partial paroxizmas.

\section{REFERENCES}

1. Sauro, K. M., Wiebe, S., Dunkley, C., Janszky, J., Kumlien, E., Moshé, S., Nakasato, N., Pedley, T. A., Perucca, E., Senties, H., Thomas, S. V., Wang, Y., Wilmshurst, J. \& Jetté, N. (2016). The current state of epilepsy guidelines: A systematic review. Epilepsia, 57, No. 1, pp. 13-23.

2. Löscher, W. \& Schmidt, D. (1988). Which animal models should be used in the search for new antiepileptic drugs? A proposal based on experimental and clinical considerations. Epilepsy Res., 2, No. 3, pp. 145-181.

3. Deshmukh, R., Thakur, A. S. \& Dewanga, D. (2011). Mechanism of action of anticonvulsant drugs: a review. Int. J. Pharm. Sci. Res., 2, No. 2, pp. 225-236.

4. Pavlovsky, V. I., Tsymbalyuk, O. V., Martynyuk, V. S., Kabanova, T. A., Semenishyna, E. A., Khalimova, E. I. \& Andronati, S. A. (2013). Analgesic effects of 3-substituted derivatives of 1,4-benzodiazepines and their possible mechanisms. Neurophysiology, 45, No. 5/6, pp. 427-432.

5. Sills G.J. (2006). The mechanisms of action of gabapentin and pregabalin. Curr. Opin. Pharmacol., 6, No. 1, pp. 108-113.

6. Golovenko, N. Ya., Larionov, V. B., Andronati, S. A., Valivodz', I. P. \& Yurpalova, T. A. (2018). Pharmacodynamic analysis of propoxazepam interaction with GABA-benzodiazepine-receptor-ionophore complex. Neurophysiology, 50, No. 1, pp. 2-10.

7. Golovenko, N. Ya., Larionov, V. B., Reder, A. S. \& Valivodz', I. P. (2017). An effector analysis of the interaction of propoxazepam with antagonists of GABA and glycine receptors. Neurochem. J., 11, No. 4, pp. 302-308.

8. Golovenko, M. Ya., Reder, A. S., Larionov, V. B. \& Balivodz', I. P. (2017). Propoxazepam influence on thiosemicarbazide-induced GABA-deficient seizures development in mice. Clin. Pharm., 21, No. 2, pp. 34-40. 
9. Urbakh, V. Yu. (1975). Statistical analysis in medical studies. Moscow: Meditsina (in Russian).

10. Varden, B. (1960). Mathematical Statistics. Moscow: Izd-vo Inostr. Lit. (in Russian).

11. Cramer, C. L., Stagnitto, M. L., Knowles, M. A. \& Palmer, G. C. (1994). Kainic acid and 4-aminopyridine seizure models in mice: evaluation of efficacy of anti-epileptic agents and calcium antagonists. Life Sci., 54, No. 16, pp. 271-275

12. Koella, W. P. (1985). Animal experimental methods in the study of antiepileptic drugs. In.: Antiepileptic drugs (pp. 283-340). Berlin, Heidelberg: Springer.

13. Bloom, P., Madeja, M., Mushhoff, U., \& Specmann, E.-J. (1996). Effects of pentylenetetrazole on GABA receptors expressed in oocytes of Xenopus laervus: extra- and intracellular sites of action. Neurosci. Let., 205, pp. 115-118.

14. Clayton, T., Chen, J. L., Ernst, M., Richter, L., Cromer, B. A., Morton, C. J., Ng, H., Kaczorowski, C. C., Helmstetter, F. J., Furtmüller, R., Ecker, G., Parker, M. W., Sieghart, W. \& Cook, J. M. (2007).An updated unified pharmacophore model of the benzodiazepine binding site on $\gamma$-aminobutyric acid ${ }_{\text {a }}$ receptors: correlation with comparative models. Curr. Med. Chem., 14, pp. 2755-2775.

Received 20.08.2018

\author{
М.Я.Головенко ${ }^{1}$, С.А Андронаті ${ }^{1}$, В.Б.Ларіонов ${ }^{1}$, А.С.Редер ${ }^{2}$ \\ ${ }^{1}$ Фізико-хімічний інститут ім. О.В. Богатського НАН України, Одеса \\ 2 ТДВ “ІнтерХім”, Одеса \\ E-mail: n.golovenko@gmail.com, office.physchem@nas.gov.ua, \\ vitaliy.larionov@gmail.com, reder@interchem.com.ua
}

\title{
ФАРМАКОЛОГІЧНИЙ ПРОФІЛЬ ПРОПОКСАЗЕПАМУ - НОВОГО ПРОТИЕПІЛЕПТИЧНОГО ЗАСОБУ
}

Проведено аналіз залежності “доза-ефект” фармакологічної дії пропоксазепаму на моделях судом у мишей, викликаних специфічними хімічними та електричними конвульсантами. Визначено особливості впливу сполуки на перебіг та перерозподіл судом різного генезу. Розраховано фармакологічні показники (терапевтичний індекс, широта, інтервал та фактор надійної безпеки), що характеризують ефективність та безпечність пропоксазепаму. Одержані дані свідчать про те, що застосування пропоксазепаму як протиепілептичного засобу є більш безпечним у випадку тих патологій, що у більшому ступені відповідають його ГАМК А $^{-}$та гліцин-ергічним механізмам дії.

Ключові слова: пропоксазепам, хімічні та електричні конвульсанти, терапевтичний індекс, иирота, інтервал, фактор надійної безпеки.

\author{
Н.Я.Головенко ${ }^{1}$, С.А Андронати ${ }^{1}$, В.Б.Ларионов ${ }^{1}$, А.С.Редер ${ }^{2}$ \\ ${ }_{1}^{1}$ Физико-химический институт им. А.В. Богатского НАН Украины, Одесса \\ 2 ОДО “ИнтерХим”, Одесса \\ E-mail: n.golovenko@gmail.com, office.physchem@nas.gov.ua, \\ vitaliy.larionov@gmail.com, reder@interchem.com.ua
}

\section{ФАРМАКОЛОГИЧЕСКИЙ ПРОФИЛЬ ПРОПОКСАЗЕПАМА - НОВОГО ПРОТИВОЭПИЛЕПТИЧЕСКОГО СРЕДСТВА}

\begin{abstract}
Проведен анализ зависимости “доза-эффект” фармакологического действия пропоксазепама на моделях судорог у мышей, вызванных специфическими химическими и электрическими конвульсантамы. Определены особенности влияния соединения на течение и перераспределение судорог различного генезиса. Рассчитаны фармакологические показатели (терапевтический индекс, широта, интервал и фактор надежной безопасности), характеризующие эффективность и безопасность пропоксазепама. Полученные данные свидетельствуют о том, что применение пропоксазепама как противоэпилептического средства является более безопасным при тех патологиях, что в большей степени соответствуют его ГАМК $\mathrm{A}^{-}$и глицин-эргическим механизмам действия.
\end{abstract}

Ключевые слова: пропоксазепам, химические и электрические конвульсанты, терапевтический индекс, широта, интервал, фактор надежной безопасности. 